\title{
Bidirectional Regulation of DARPP-32 Phosphorylation by Dopamine
}

\author{
Akinori Nishi, Gretchen L. Snyder, and Paul Greengard \\ Laboratory of Molecular and Cellular Neuroscience, The Rockefeller University, New York, New York 10021
}

Dopamine has been shown to stimulate phosphorylation of DARPP-32, a phosphoprotein highly enriched in medium-sized spiny neurons of the neostriatum. Here, we investigated the contribution of D1-like and D2-like dopamine receptors in the regulation of DARPP-32 phosphorylation in mouse striatal slices. D1-like and D2-like receptors had opposing effects on the state of DARPP-32 phosphorylation. The D1 receptor agonist SKF82526 increased DARPP-32 phosphorylation. In contrast, the D2 receptor agonist quinpirole decreased basal as well as D1 agonist-, forskolin-, and 8-bromo-cAMP-stimulated phosphorylation of DARPP-32. The ability of quinpirole to decrease D1-stimulated DARPP-32 phosphorylation was calcium-dependent and was blocked by the calcineurin inhib- itor cyclosporin A, suggesting that the D2 effect involved an increase in intracellular calcium and activation of calcineurin. In support of this interpretation, $\mathrm{Ca}^{2+}$-free/EGTA medium induced a greater than 60-fold increase in DARPP-32 phosphorylation and abolished the ability of quinpirole to dephosphorylate DARPP-32. The antipsychotic drug raclopride, a selective D2 receptor antagonist, increased phosphorylation of DARPP-32 under basal conditions and in D2 agonist-treated slices. The results of this study demonstrate that dopamine exerts a bidirectional control on the state of phosphorylation of DARPP-32.

Key words: DARPP-32; dopamine; D2 receptor; phosphorylation; neostriatum; calcineurin; raclopride
DARPP-32, a dopamine- and cAMP-regulated phosphoprotein of $M_{\mathrm{r}} 32,000$, is a cytosolic protein that is selectively enriched in medium-sized spiny neurons in neostriatum (Ouimet et al., 1984; Walaas and Greengard, 1984). DARPP-32 is phosphorylated by cAMP-dependent protein kinase (PKA) on a single threonine residue, $\mathrm{thr}^{34}$, resulting in its conversion into a potent inhibitor of protein phosphatase-1 (Hemmings et al., 1984). DARPP-32 can be dephosphorylated and inactivated in vitro by the calcium/ calmodulin-dependent protein phosphatase calcineurin (King et al., 1984). Dopamine has been shown to stimulate the phosphorylation of DARPP-32 in neostriatum by activation of a biochemical cascade involving stimulation of D1 receptors, activation of adenylyl cyclase, increased cAMP formation, and increased activity of PKA (Walaas and Greengard, 1984). The selective enrichment of DARPP-32 in dopaminoceptive neurons and its regulation by dopamine strongly indicate that DARPP-32, by regulating protein phosphatase- 1 activity, plays a key role in mediating the effects of dopamine on these cells. The control of protein phosphatase- 1 activity by DARPP-32 is likely to have a significant role in the regulation of neuronal excitability. For instance, in neostriatum, dopamine-mediated effects on the function of calcium channels (Surmeier et al., 1994), voltagedependent sodium channels (Surmeier et al., 1992; Schiffman et al., 1994), and $\mathrm{Na}^{+}, \mathrm{K}^{+}$-ATPase (Aperia et al., 1991) are regulated directly or indirectly by protein phosphatase- 1 .

Medium-sized spiny neurons of the neostriatum and nucleus

Received May 27, 1997; revised July 18, 1997; accepted Aug. 13, 1997.

This research was supported by Grant MH40899 from the United States Public Health Service (P.G.). The authors thank Drs. Angus C. Nairn and Gilberto Fisone for helpful discussion. Cyclosporin A was kindly provided by Abbott Laboratories and SKF82526 by SK\&F Laboratories.

Correspondence should be addressed to Dr. Paul Greengard, Laboratory of Molecular and Cellular Neuroscience, The Rockefeller University, 1230 York Avenue, New York, NY 10021.

Copyright (C) 1997 Society for Neuroscience $0270-6474 / 97 / 178147-09 \$ 05.00 / 0$ accumbens receive dopaminergic input from cell bodies in the midbrain (Anden et al., 1964; Poirier and Sourkes, 1965; Swanson, 1982). To date, five dopamine receptor subtypes have been identified that constitute two major subclasses, a D1 subfamily (D1 and D5 subtypes) and a D2 subfamily (D2, D3, and D4 subtypes) (Sibley and Monsma, 1992). D1 and D2 dopamine receptors are abundantly expressed on cell bodies and dendritic processes of medium spiny neurons (Levey et al., 1993). Messenger RNAs coding for each of the other dopamine receptor subtypes (i.e., D3, D4, and D5) have been isolated from individual neostriatal neurons (Surmeier et al., 1996), but whether these receptor proteins are expressed in medium spiny neurons and how they functionally interact with D1 and D2 receptors is still unclear.

There is considerable evidence for either synergistic or opposing interactions of D1- and D2-like dopamine receptors at the biochemical, physiological, and behavioral level (for review, see Jackson and Westlind-Danielsson, 1994). Biochemically, D1 and D2 receptors have opposing actions on the activity of adenylyl cyclase in neostriatal neurons: D2 receptors inhibit adenylyl cyclase activity (Stoof and Kebabian, 1981), whereas activation of D1 receptors increases cAMP formation by adenylyl cyclase. More recent studies have shown that D2-like dopamine receptors, via interactions with specific G-proteins, can be coupled to multiple effector systems, including calcium channels, potassium channels, and phospholipase C (for review, see Huff, 1996). For example, Yan et al. (1996) showed that D2 receptors on neostriatal neurons negatively couple to calcium channels through a $G_{i / o}$ class protein. In addition, activation of D2 receptors apparently decreases sodium currents in medium spiny neostriatal neurons through a membrane-delimited pathway and increases these currents through a soluble second messenger pathway (presumably involving inhibition of adenylyl cyclase) (Surmeier et al., 1992).

The aim of the present study was to determine the relative 

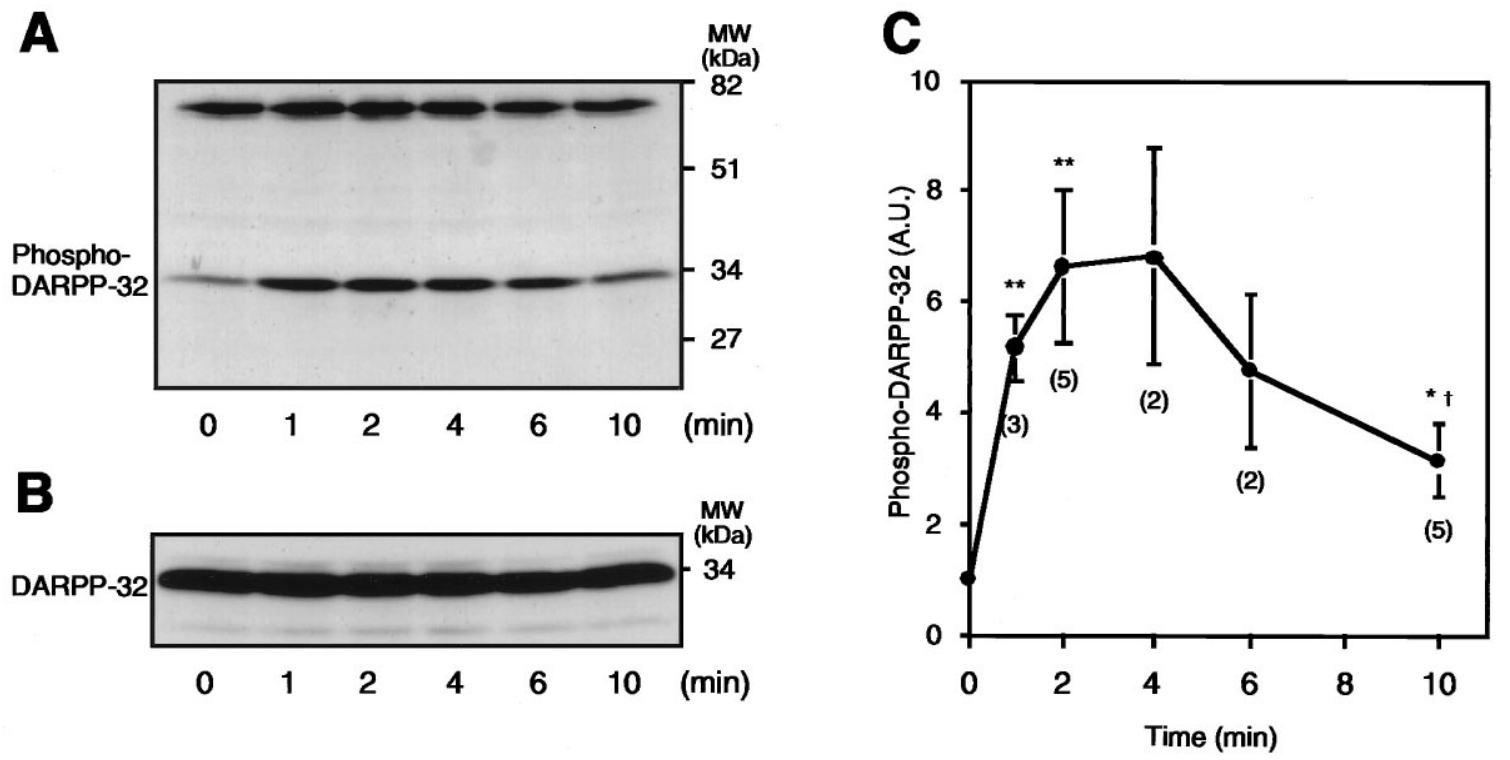

Figure 1. Effect of dopamine on the level of phospho-DARPP-32 in neostriatum. Slices were incubated with dopamine (100 $\mu \mathrm{M})$ in the presence of the dopamine uptake inhibitor nomifensine $(10 \mu \mathrm{M})$ for the indicated times. $A$, Phospho-DARPP-32 was detected at a molecular mass of $\sim 32 \mathrm{kDa}$ using $\mathrm{mAb}-23$ against thr ${ }^{34}$-phospho-DARPP-32. Note that the phospho-DARPP-32 mAb also detected a cross-reactive protein band at a molecular mass of $\sim 75 \mathrm{kDa}$, the levels of which were not affected by dopamine. $B$, Total DARPP-32 was detected in the same membrane as shown in $A$ using mAb C24-5a against DARPP-32. $C$, The amount of phospho-DARPP-32 was quantitated by densitometry, and the data were normalized to values obtained with untreated tissue. Data represent mean \pm SEM for the number of experiments shown in parentheses. ${ }^{*} p<0.05,{ }^{* *} p<0.01$ compared with 0 min; $\dagger p<0.05$ compared with 2 min.

contribution of D1- and D2-like dopamine receptors to dopamine signaling through the DARPP-32/protein phosphatase- 1 cascade, the possible biochemical pathways involved, and the possible effect on this signaling cascade of a widely used antipsychotic drug, raclopride.

\section{MATERIALS AND METHODS}

Preparation and incubation of striatal slices. Male C57BL/6 mice (5-8 weeks old) were decapitated. The brains were removed rapidly and placed in ice-cold, oxygenated $\mathrm{Krebs}-\mathrm{HCO}_{3}{ }^{-}$buffer $(124 \mathrm{~mm} \mathrm{NaCl}, 4$ $\mathrm{mm} \mathrm{KCl}, 26 \mathrm{~mm} \mathrm{NaHCO} 3,1.5 \mathrm{~mm} \mathrm{CaCl}_{2}, 1.25 \mathrm{~mm} \mathrm{KH}_{2} \mathrm{PO}_{4}, 1.5 \mathrm{~mm}$ $\mathrm{MgSO}_{4}$, and $10 \mathrm{~mm}$ D-glucose, $\left.\mathrm{pH} 7.4\right)$. Coronal slices $(350 \mu \mathrm{m})$ were prepared using a vibratome. Striatum and nucleus accumbens were dissected from the slices in ice-cold $\mathrm{Krebs}-\mathrm{HCO}_{3}{ }^{-}$buffer. Each slice was placed in a polypropylene incubation tube with $2 \mathrm{ml}$ of fresh Krebs$\mathrm{HCO}_{3}{ }^{-}$buffer containing adenosine deaminase $(10 \mu \mathrm{g} / \mathrm{ml})$. The slices were preincubated at $30^{\circ} \mathrm{C}$ under constant oxygenation with $95 \% \mathrm{O}_{2} / 5 \%$ $\mathrm{CO}_{2}$ for $60 \mathrm{~min}$. The buffer was replaced with fresh Krebs- $\mathrm{HCO}_{3}{ }^{-}$buffer after $30 \mathrm{~min}$ of preincubation. In some experiments, slices were incubated in $\mathrm{Ca}^{2+}$-free/EGTA medium (124 mM NaCl, $4 \mathrm{~mm} \mathrm{KCl}, 26 \mathrm{~mm}$ $\mathrm{NaHCO}_{3}, 1.25 \mathrm{~mm} \mathrm{KH} \mathrm{KO}_{4}, 3.0 \mathrm{~mm} \mathrm{MgSO}$, $10 \mathrm{~mm}$ D-glucose, and 1 mM EGTA, pH 7.4) for 20 min after 60 min of preincubation in Krebs$\mathrm{HCO}_{3}{ }^{-}$buffer. Slices were treated with drugs as specified in each experiment. Drugs were obtained from the following sources: quinpirole, raclopride, SCH23390, NMDA, and MK-801 from Research Biochemicals (Natick, MA); calyculin A, forskolin, and thapsigargin from LC laboratories; and 8-bromo-cAMP from Sigma (St. Louis, MO). After the drug treatment, slices were transferred to Eppendorf tubes, frozen on dry ice, and stored at $-80^{\circ} \mathrm{C}$ until assayed.

Immunoblotting. Frozen tissue samples were sonicated in boiling $1 \%$ SDS and boiled for an additional $10 \mathrm{~min}$. Small aliquots of the homogenate were retained for protein determination by the BCA protein assay method (Pierce, Rockford, IL) using bovine serum albumin as a standard. Equal amounts of protein $(100 \mu \mathrm{g})$ were loaded onto $12 \%$ acrylamide gels, and the proteins were separated by SDS-PAGE and transferred to nitrocellulose membranes $(0.2 \mu \mathrm{m})$ (Schleicher \& Schuell, Keene, NH) by the method of Towbin et al. (1979). The membranes were immunoblotted using a monoclonal antibody (mAb-23; 1:750 dilution) (Snyder et al., 1992), which is a phosphorylation state-specific antibody raised against a DARPP-32 peptide containing phospho-thr ${ }^{34}$, the site phosphorylated by cAMP-dependent protein kinase. A mAb (C24-5a; 1:7500 dilution) generated against DARPP-32 (Hemmings and Greengard, 1986), which is not phosphorylation state-specific, was used to estimate the total amount of DARPP-32 in samples. None of the experimental manipulations used in the present study altered the total amount of DARPP-32.

Antibody binding was revealed by incubation with goat anti-mouse horseradish peroxidase-linked IgG (1:6000-8000 dilution) (Pierce) and the ECL immunoblotting detection system (Amersham, Arlington Heights, IL). Chemiluminescence was detected by autoradiography using DuPont NEN autoradiography film, and phosphorylated (phospho-)DARPP-32 bands were quantified by densitometry using a Bio-Rad model 620 video densitometer and Bio-Rad 1-D Analyst software (BioRad, Hercules, CA).

Data were analyzed by Student's $t$ test with significance defined as $p<0.05$.

\section{RESULTS}

\section{Effect of dopamine on the level of phospho-DARPP-32}

Dopamine has been shown to increase the state of phosphorylation of DARPP-32 in rat neostriatum (Walaas et al., 1983). In this study, the effect of dopamine on DARPP-32 phosphorylation in mouse neostriatal slices was examined using a phosphorylation state-specific antibody that selectively detected phosphorylation at the cAMP-dependent site $\left(\mathrm{thr}^{34}\right)$. $\mathrm{Thr}^{34}$-phospho-DARPP-32 was detectable in untreated slices. The stoichiometry of DARPP-32 phosphorylation was estimated to be $0.5-1.0 \%$ under basal conditions. Treatment of slices with dopamine $(100 \mu \mathrm{M})$, plus the dopamine uptake inhibitor nomifensine $(10 \mu \mathrm{M})$, increased the level of phospho-DARPP-32 by $6.64 \pm 1.36$-fold ( $p<$ $0.01)$. DARPP-32 phosphorylation was maximal at 2-4 min of incubation, and the level of phospho-DARPP-32 subsequently decreased (Fig. 1). The total amount of DARPP-32, determined using the DARPP-32 antibody C24-5a, was similar in each sample.

The phosphorylation state-specific antibody for thr $^{34}$-phospho- 
DARPP-32 also detects the $\mathrm{thr}^{35}$-phosphorylated form of inhibitor-1, a protein phosphatase-1 inhibitor that is closely related structurally and functionally to DARPP-32 (Aitkin et al., 1982; Williams et al., 1986). Although detectable levels of inhibitor-1 are expressed in medium-sized spiny neurons of the neostriatum, the level of thr $^{35}$-phosphorylated inhibitor-1 was below the sensitivity of detection in both control and dopaminetreated samples (data not shown).

\section{Effect of D1 and D2 agonists on the level of phospho-DARPP-32}

Because both D1-like and D2-like dopamine receptors are expressed in neostriatum, the role of each of these dopamine receptor subclasses in the regulation of DARPP-32 phosphorylation was studied. The D1 agonist SKF82526 (1 $\mu \mathrm{M})$ increased the level of phospho-DARPP-32 by $5.37 \pm 0.99$-fold $(p<0.01)$. DARPP-32 phosphorylation was maximal at 5-10 min of incubation, and the level of phosphorylation subsequently decreased (Fig. 2A). The effect of SKF82526 on DARPP-32 phosphorylation was dose-dependent with a half-maximal effect at $\sim 100 \mathrm{nM}$ and was abolished by the D1 antagonist SCH23390 (data not shown).

Quinpirole $(1 \mu \mathrm{M})$, a D2-like receptor agonist, decreased both the basal level (Fig. 2B) and the SKF82526-stimulated level (Fig. 3 ) of phospho-DARPP-32. The effect of quinpirole on the basal level was observed within $1 \mathrm{~min}$ of incubation and was sustained for at least $15 \mathrm{~min}$ (Fig. 2B). SKF82526 alone increased the level of phospho-DARPP-32 by $9.36 \pm 2.06$-fold in this series of experiments, and quinpirole at a concentration of $10 \mathrm{nM}$ to $1 \mu \mathrm{M}$ significantly reduced the SKF82526-stimulated DARPP-32 phosphorylation (Fig. 3). A near-maximal effect of quinpirole was observed at a concentration of $100 \mathrm{nM}$, at which concentration phospho-DARPP-32 decreased to $\sim 60 \%$ of the SKF82526stimulated level. These results clearly indicate that drugs which activate D1- and D2-like dopamine receptors have opposing effects on the state of phosphorylation of DARPP-32.

\section{Effect of the antipsychotic drug raclopride on the level of phospho-DARPP-32}

Most antipsychotic drugs block D2-like dopamine receptors with potencies proportional to their clinical antipsychotic potencies. We examined whether the antipsychotic drug raclopride regulated DARPP-32 phosphorylation in neostriatal slices. Raclopride was chosen as the antipsychotic drug of choice because of its potent and selective interaction with $\mathrm{D} 2$-like receptors relative to D1-like receptors (Seeman and Van Tol, 1994). Treatment with raclopride $(1 \mu \mathrm{M})$ for 20 min slightly increased the basal level of phospho-DARPP-32 (Fig. 4A), suggesting a tonic activation of D2 receptors under basal conditions. The ability of quinpirole (100 nM) to decrease the level of phospho-DARPP-32 under basal conditions was blocked by raclopride. SKF82526 increased the level of phospho-DARPP-32 to a similar extent in the presence and absence of raclopride. However, the ability of quinpirole to decrease the SKF82526-stimulated level of phospho-DARPP-32 was dramatically reduced by raclopride. These results indicate that the action of antipsychotic drugs that block D2-like dopamine receptors involves regulation of the state of phosphorylation of DARPP-32.

Effects of SKF82526, quinpirole, and raclopride, similar to those seen in the neostriatum, were also observed in the nucleus accumbens (Fig. 4B). In the nucleus accumbens, SKF82526 increased the level of phospho-DARPP-32 (by about sevenfold),
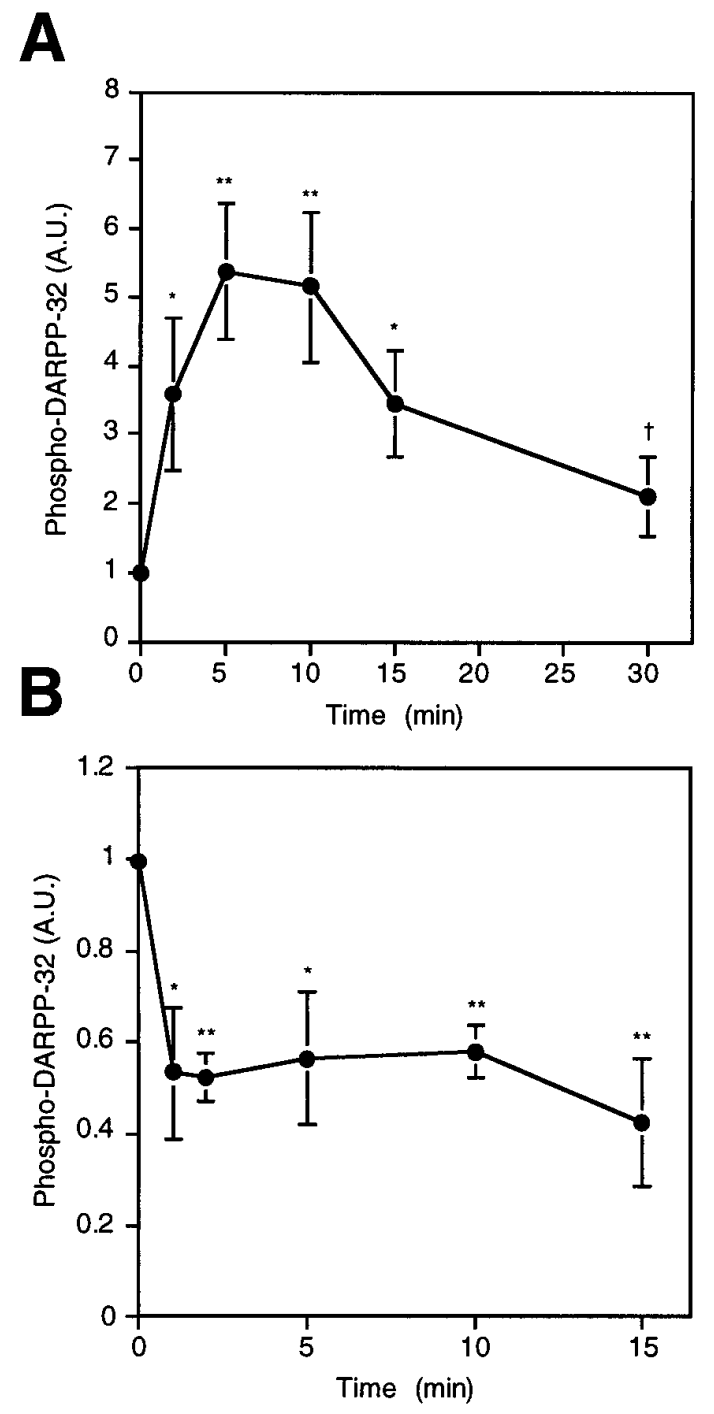

Figure 2. Effects of D1 agonist (SKF82526) and D2 agonist (quinpirole) on the basal level of phospho-DARPP-32 in neostriatum. Slices were incubated with $(A)$ SKF82526 $(1 \mu \mathrm{M})$ or $(B)$ quinpirole $(1 \mu \mathrm{M})$ for the indicated times. The amount of phospho-DARPP-32 was quantitated by densitometry, and the data were normalized to values obtained with untreated tissue. Data represent mean \pm SEM for 4-12 experiments. ${ }^{*} p<0.05,{ }^{* *} p<0.01$ compared with $0 \mathrm{~min} ; \dagger p<0.05$ compared with $5 \mathrm{~min}$.

whereas quinpirole decreased the basal level of DARPP-32 phosphorylation (by $\sim 50 \%$ ). Quinpirole also decreased the SKF82526-stimulated DARPP-32 phosphorylation by $\sim 60 \%$. Raclopride alone induced a small increase in the basal level of phospho-DARPP-32. In addition, raclopride abolished the quinpirole-induced decrease in basal DARPP-32 phosphorylation as well as the quinpirole-induced decrease in SKF82526stimulated DARPP-32 phosphorylation.

\section{Effect of D2 agonist on stimulated levels of phospho-DARPP-32}

The ability of the D2 agonist quinpirole to reduce the basal and D1 agonist-stimulated levels of phospho-DARPP-32 could be explained in at least two ways (see Fig. 8). Because the activation of D2-like dopamine receptors has been reported to inhibit adenylyl cyclase through a $\mathrm{G}_{\mathrm{i}}$-mediated mechanism, it is possible 


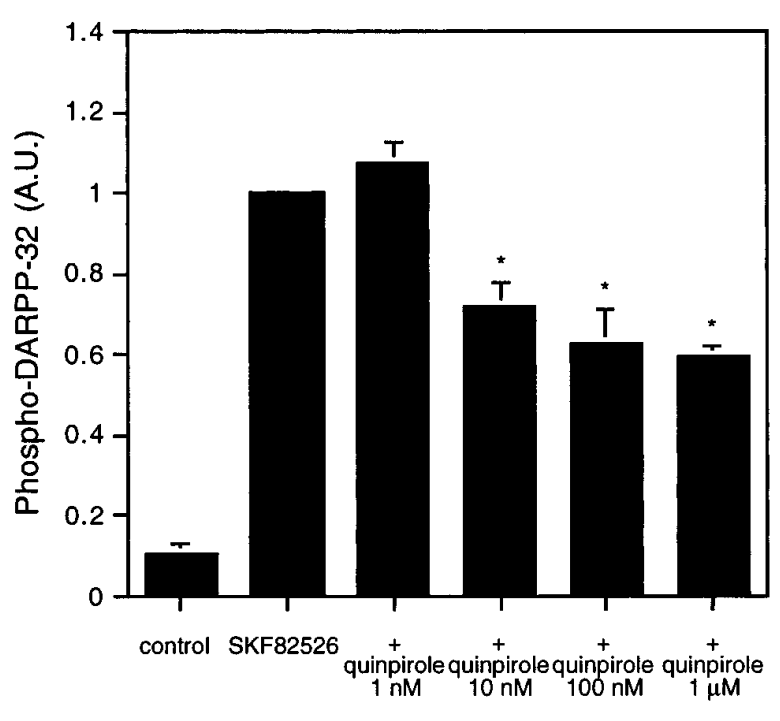

Figure 3. Opposing effects of D1 agonist (SKF82526) and D2 agonist (quinpirole) on the level of phospho-DARPP-32 in neostriatum. Slices were preincubated with the indicated concentrations of quinpirole $(1 \mathrm{nM}$ to $1 \mu \mathrm{M})$ for $5 \mathrm{~min}$ and then incubated with quinpirole plus SKF82526 (1 $\mu \mathrm{M})$ for an additional $5 \mathrm{~min}$. The amount of phospho-DARPP-32 was quantitated by densitometry, and the data were normalized to values obtained with SKF82526 alone. Data represent mean \pm SEM for four to five experiments. ${ }^{*} p<0.01$ compared with SKF82526 alone.

that D2 receptor agonists decrease DARPP-32 phosphorylation by inhibiting D1 receptor-mediated increases in cAMP formation. Alternatively, activation of D2-like dopamine receptors might increase the activity of calcineurin, a calcium/calmodulindependent protein phosphatase, which has been shown to dephosphorylate phospho-DARPP-32 (King et al., 1984; Halpain et al., 1990). To evaluate the relative contributions of the cAMP and calcineurin pathways to the regulation of DARPP-32 phosphorylation by a D2 agonist, we examined the ability of quinpirole to regulate DARPP-32 phosphorylation in the presence of forskolin or the cAMP analog 8-bromo-cAMP. Treatment of neostriatal slices with forskolin $(10 \mu \mathrm{M})$, a direct activator of adenylyl cyclase, increased the level of phospho-DARPP-32 by 20 -fold after $5 \mathrm{~min}$. The D2-like receptor agonist quinpirole $(1 \mu \mathrm{M})$ reduced the forskolin-stimulated DARPP-32 phosphorylation by 35\% (Fig. 5), indicating that the effect of quinpirole occurred downstream of the D1 receptor. When neostriatal slices were treated with 8bromo-cAMP (1 mM) for $5 \mathrm{~min}$, the level of phospho-DARPP-32 increased by 25 -fold, and quinpirole $(1 \mu \mathrm{M})$ reduced this increase by $30 \%$. This result indicates that the stimulation of D2-like dopamine receptors in striatum decreases DARPP-32 phosphorylation, in part, through a mechanism other than inhibition of adenylyl cyclase activity.

\section{Effect of Ca-free/EGTA medium on the level of phospho-DARPP-32}

We next determined whether the regulation of DARPP-32 phosphorylation by quinpirole was $\mathrm{Ca}^{2+}$-dependent. Incubation of slices in $\mathrm{Ca}^{2+}$-free/EGTA medium for $20 \mathrm{~min}$ increased the level of phospho-DARPP-32 by $61.8 \pm 10.7$-fold (Fig. 6). The effect of $\mathrm{Ca}^{2+}$-free/EGTA medium was much larger than the effect of forskolin or 8-bromo-cAMP. When $\mathrm{Ca}^{2+}$-free/EGTA medium was replaced by normal Krebs- $\mathrm{HCO}_{3}{ }^{-}$buffer $\left(\mathrm{Ca}^{2+}, 1.5 \mathrm{~mm}\right)$, DARPP-32 was dephosphorylated (data not shown). These results indicate that the phosphorylation of DARPP-32 is tightly
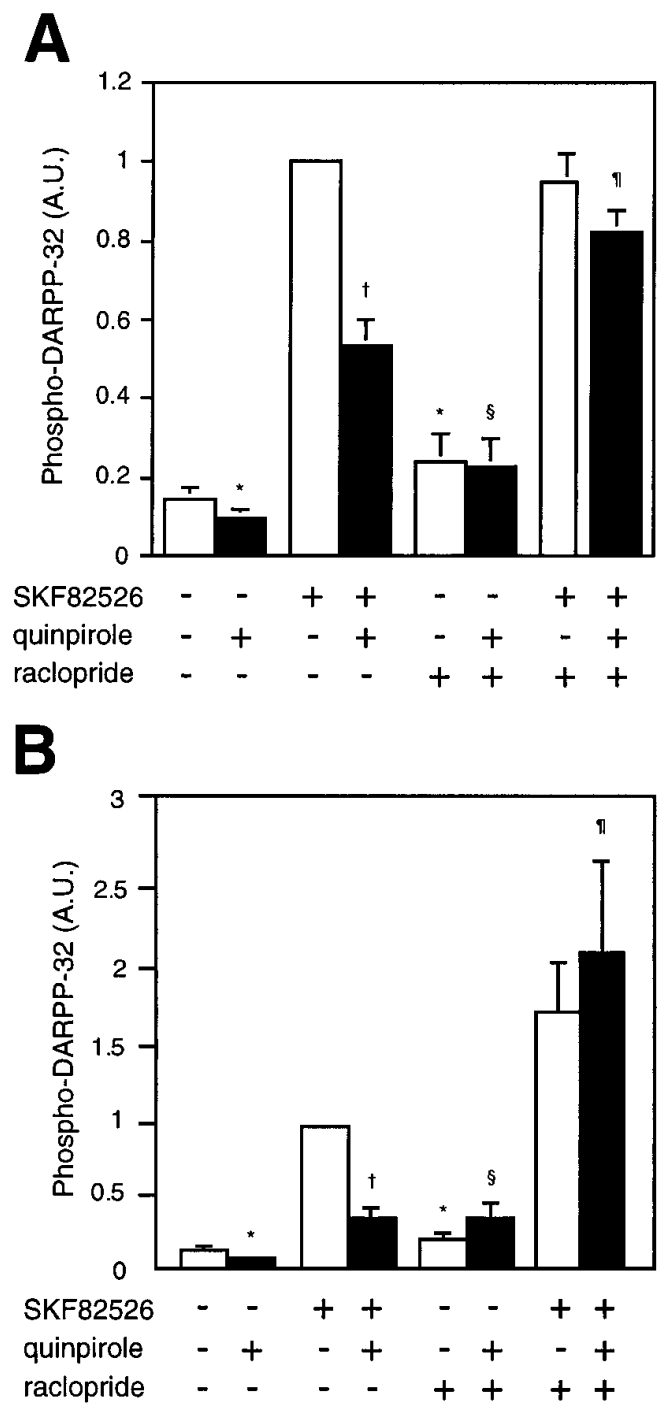

Figure 4. Effect of the antipsychotic drug raclopride on the level of phospho-DARPP-32 in $(A)$ neostriatum and $(B)$ nucleus accumbens. Slices were incubated for a total of $20 \mathrm{~min}$. Raclopride $(1 \mu \mathrm{M})$ was added at $0 \mathrm{~min}$, quinpirole $(100 \mathrm{nM})$ at $10 \mathrm{~min}$, and SKF82526 $(1 \mu \mathrm{M})$ at $15 \mathrm{~min}$ of incubation. The amount of phospho-DARPP-32 was quantitated by densitometry, and the data were normalized to values obtained with SKF82526 alone. $A$, Data represent mean \pm SEM for six to nine experiments. ${ }^{*} p<0.01$ compared with no addition; $\dagger p<0.01$ compared with SKF82526 alone; $\$ p<0.05$ compared with quinpirole alone; $\mathbb{\text { I }} p<0.01$ compared with SKF82526 plus quinpirole. $B$, Data represent mean \pm SEM for five to seven experiments. ${ }^{*} p<0.05$ compared with no addition; $\dagger p<0.01$ compared with SKF82526 alone; $\S p<0.01$ compared with quinpirole alone; ๆ $p<0.02$ compared with SKF82526 plus quinpirole.

regulated by $\mathrm{Ca}^{2+}$ and support a role for calcineurin in the regulation of DARPP-32 phosphorylation.

Under $\mathrm{Ca}^{2+}$-free conditions (Fig. 7), SKF82526, forskolin, and 8-bromo-cAMP each increased the level of phospho-DARPP-32, over the already high basal levels, by $1.55 \pm 0.12-, 2.04 \pm 0.22-$, and $2.42 \pm 0.53$-fold, respectively. Under each of these conditions, quinpirole failed to decrease the level of phospho-DARPP32. These results further suggest that the effect of D2-like receptor activation is mediated in a $\mathrm{Ca}^{2+}$-dependent manner.

The possible involvement of the calcium/calcineurin pathway in the regulation of DARPP-32 phosphorylation was further examined by the use of thapsigargin, which increases intracellular 
A

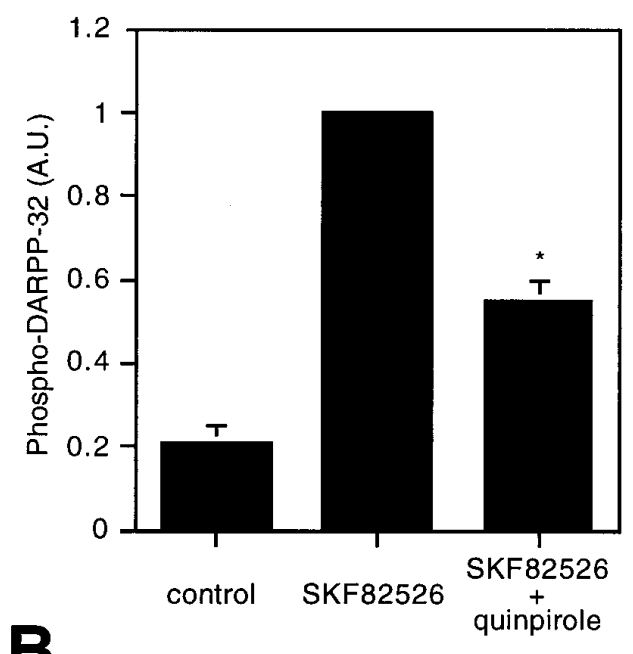

B
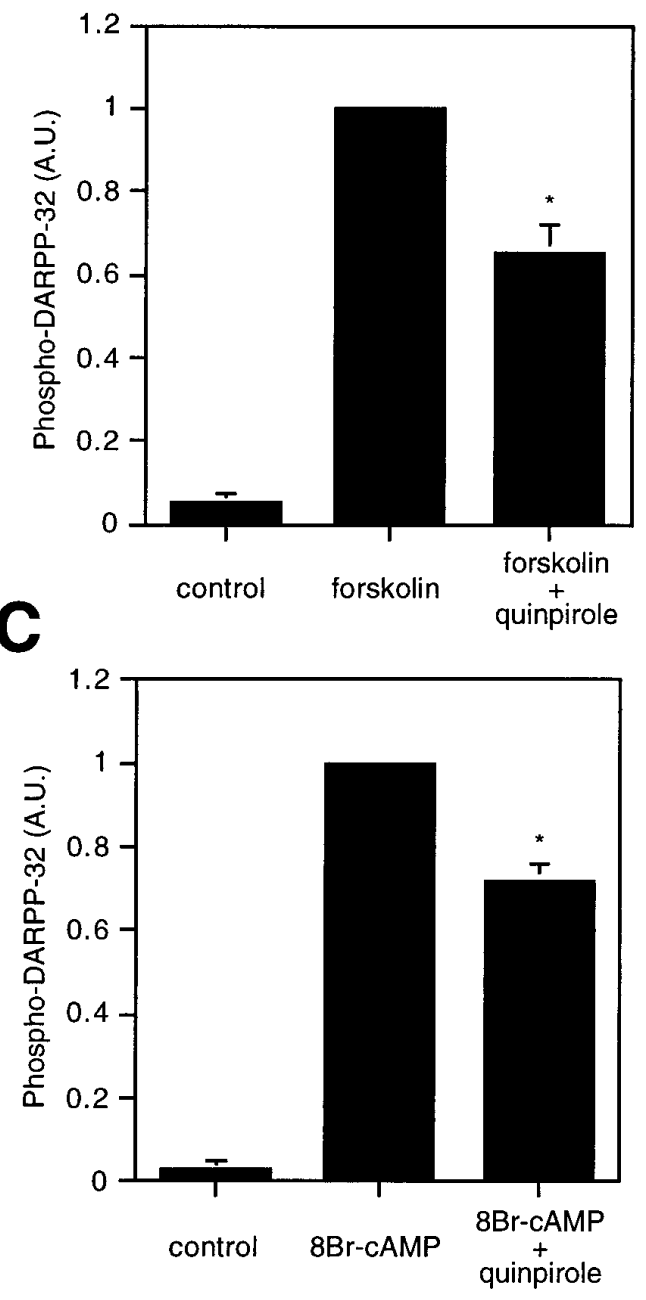

Figure 5. Effect of D2 agonist (quinpirole) on stimulated levels of phospho-DARPP-32 in neostriatum. Slices were preincubated with quinpirole $(1 \mu \mathrm{M})$ for $5 \mathrm{~min}$ and then incubated with quinpirole plus either $(A)$ SKF82526 $(1 \mu \mathrm{M}),(B)$ forskolin $(10 \mu \mathrm{M})$, or $(C)$ 8-bromo-cAMP (1 mM) for an additional $5 \mathrm{~min}$. The amount of phospho-DARPP-32 was quantitated by densitometry, and the data were normalized to values obtained with SKF82526, forskolin, or 8-bromo-cAMP alone. Data represent mean \pm SEM for three to four experiments. ${ }^{*} p<0.01$ compared with SKF82526, forskolin, or 8-bromo-cAMP alone.
A

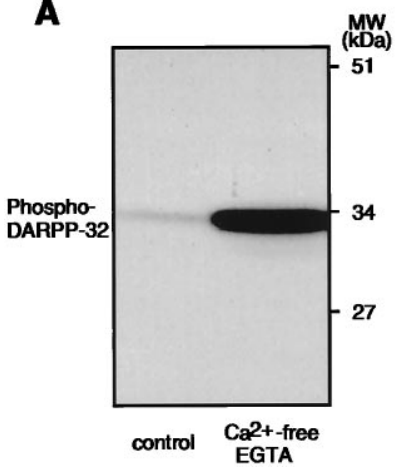

B

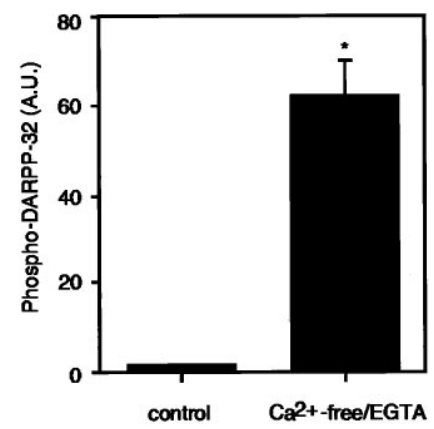

Figure 6. Effect of $\mathrm{Ca}^{2+}$-free/EGTA medium on the level of phosphoDARPP-32 in neostriatum. Slices were incubated in control or $\mathrm{Ca}^{2+}$-free/ EGTA medium for $20 \mathrm{~min}$. $A$, Phospho-DARPP-32 was detected using a phosphorylation state-specific mAb (mAb-23). $B$, The amount of phospho-DARPP-32 was quantitated by densitometry, and the data were normalized to values obtained with control. Data represent mean \pm SEM for four experiments. ${ }^{*} p<0.01$ compared with control.

$\mathrm{Ca}^{2+}$ levels by inhibition of endoplasmic reticulum $\mathrm{Ca}^{2+}$. ATPase (Thastrup et al., 1990). The level of phospho-DARPP-32 seen after incubation of neostriatal slices with SKF82526 (1 $\mu \mathrm{M})$ for 5 min was reduced by $46.9 \pm 7.7 \%$ when thapsigargin $(5 \mu \mathrm{M})$ was added to the medium 5 min before addition of the D1 agonist. These results suggest that release of $\mathrm{Ca}^{2+}$ from intracellular stores can modulate DARPP-32 phosphorylation.

\section{Effect of cyclosporin A on the level of phospho-DARPP-32}

The effect of cyclosporin A, a specific inhibitor of calcineurin, on the level of phospho-DARPP-32 is shown in Table 1. Basal levels of phospho-DARPP-32 were increased 11- to 16 -fold by cyclosporin A. Moreover, this calcineurin inhibitor acted synergistically with SKF82526 to increase the level of phospho-DARPP-32 and prevented the decrease that occurred after prolonged incubation of slices with the D1 agonist alone (Table 1A). Although cyclosporin A increased the basal level of phospho-DARPP-32 dramatically, a quinpirole-induced decrease in the level of phospho-DARPP-32 was still observed in its presence (Table 1B). These results suggest that a D2 agonist-induced decrease in the low, basal level of cAMP contributes to the ability of quinpirole to reduce DARPP-32 phosphorylation. In contrast, cyclosporin A abolished the ability of quinpirole to decrease the SKF82526stimulated phosphorylation of DARPP-32 (Table 1C). These results indicate that when calcineurin is inhibited in the presence of SKF82526, quinpirole does not reduce the level of cAMP below that sufficient for optimal phosphorylation of DARPP-32.

\section{Effect of D2 agonist on the level of phospho-DARPP- 32 is not mediated through the NMDA receptor}

The activation of NMDA receptors decreases the phosphorylation of DARPP-32 in the neostriatum (Halpain et al., 1990). This effect has been hypothesized to occur through a mechanism involving increased intracellular calcium and activation of calcineurin. We have examined whether the D2-mediated regulation of DARPP-32 phosphorylation requires activation of NMDA receptors. Although both NMDA and quinpirole antagonized the ability of SKF82526 to increase the level of phospho-DARPP-32, the effect of NMDA, but not that of quinpirole, was abolished by the NMDA receptor antagonist MK801 (Table 2). These results indicate that the ability of 
A
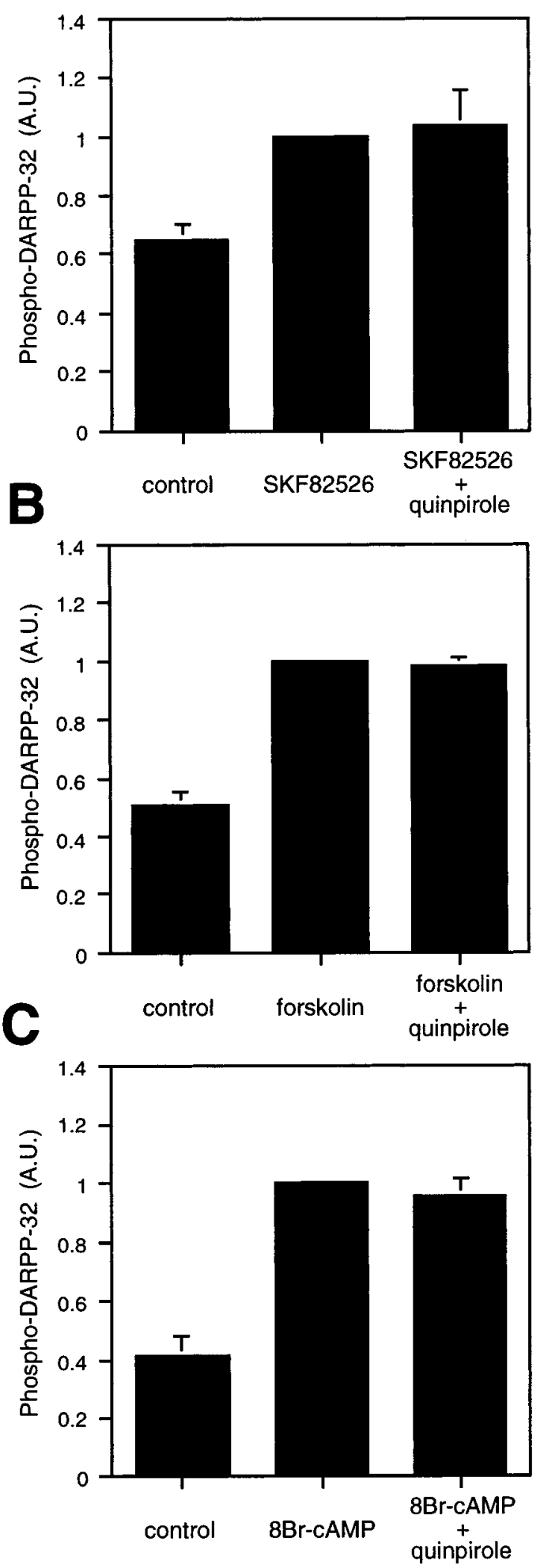

Figure 7. Absence of effect of D2 agonist (quinpirole) on the level of phospho-DARPP- 32 in $\mathrm{Ca}^{2+}$-free/EGTA medium. Neostriatal slices were incubated in $\mathrm{Ca}^{2+}$-free/EGTA medium for a total of $20 \mathrm{~min}$. Buffer was replaced by $\mathrm{Ca}^{2+}$-free/EGTA medium at $0 \mathrm{~min}$, quinpirole $(1 \mu \mathrm{M})$ was added at $10 \mathrm{~min}$, and $(A) \mathrm{SKF} 82526(1 \mathrm{mM}),(B)$ forskolin $(10 \mu \mathrm{M})$, or $(C)$ 8-bromo-cAMP (1 mM) was added at $15 \mathrm{~min}$ of incubation. The amount of phospho-DARPP-32 was quantitated by densitometry, and the data were normalized to values obtained with SKF82526, forskolin, or 8-bromocAMP alone. Data represent mean \pm SEM for three to four experiments.
Table 1. Effect of cyclosporin A on the level of phospho-DARPP-32 in neostriatum

Cyclosporin A (-) Cyclosporin A (+)

A. D1 agonist SKF82526

$\begin{array}{lll}0 \mathrm{~min} & 1.00 & 16.0 \pm 1.6^{*} \\ 5 \mathrm{~min} & 7.14 \pm 0.97^{*} & 31.6 \pm 2.8^{* *} \\ 30 \mathrm{~min} & 3.07 \pm 0.66^{*, * * *} & 28.0 \pm 3.1^{* *}\end{array}$

B. D2 agonist quinpirole

$\begin{array}{llr}0 \mathrm{~min} & 1.00 & 13.50 \pm 1.74^{*} \\ 2 \mathrm{~min} & 0.525 \pm 0.051^{*} & 5.98 \pm 1.28^{* *} \\ 10 \mathrm{~min} & 0.580 \pm 0.058^{*} & 5.60 \pm 1.05^{* *}\end{array}$

C. D1 + D2 agonist

$\begin{array}{lcl}\text { Control } & 1.00 & 11.0 \pm 2.5^{*} \\ \text { SKF82526 } & 10.61 \pm 2.28^{*} & 21.1 \pm 2.3^{* *} \\ \text { SKF82526 + quinpirole } & 4.78 \pm 1.20^{* * * *} & 20.3 \pm 2.5^{* *}\end{array}$

Slices were preincubated in the absence or presence of cyclosporin A (CyA) (5 $\mu \mathrm{M})$ for $60 \mathrm{~min}$, followed by the addition of SKF82526 and/or quinpirole. The amount of phospho-DARPP-32 was quantitated by densitometry, and the data were normalized to values obtained with control. A, Slices were incubated with SKF82526 (1 $\mu \mathrm{M})$ for the indicated times. Data represent means \pm SEM for five to nine experiments. $* p<0.01$ compared with $0 \mathrm{~min} / \mathrm{CyA}(-)$; ** $p<0.01$ compared with $0 \mathrm{~min} / \mathrm{CyA}$ $(+) ; * * * p<0.01$ compared with $5 \mathrm{~min} / \mathrm{CyA}(-)$. B. Slices were incubated with quinpirole $(1 \mu \mathrm{M})$ for the indicated times. Data represent means \pm SEM for five to seven experiments. * $p<0.01$ compared with $0 \mathrm{~min} / \mathrm{CyA}(-) ;{ }^{* *} p<0.01$ compared with $0 \mathrm{~min} / \mathrm{CyA}(+)$. C, Slices were preincubated with quinpirole $(1 \mu \mathrm{M})$ for $5 \mathrm{~min}$ and then incubated with quinpirole plus SKF82526 $(1 \mu \mathrm{M})$ for an additional $5 \mathrm{~min}$. Data represent means \pm SEM for six to nine experiments. ${ }^{*} p<0.01$ compared with control/CyA (-); ** $p<0.01$ compared with control/CyA $(+) ; * * * p<0.05$ compared with SKF82526/CyA (-).

Table 2. Effect of D2 agonist on the level of phospho-DARPP-32 is not mediated through the NMDA receptor

\begin{tabular}{lll} 
& MK801 $(-)$ & MK801 $(+)$ \\
\hline Control & $0.103 \pm 0.021^{*}$ & $0.247 \pm 0.044^{* *}$ \\
SKF82526 & 1.000 & $1.115 \pm 0.078$ \\
SKF82526 + NMDA & $0.042 \pm 0.009^{*}$ & $1.042 \pm 0.085$ \\
SKF82526 + quinpirole & $0.598 \pm 0.137^{*}$ & $0.616 \pm 0.084^{* * *}$
\end{tabular}

Neostriatal slices were incubated for a total of $20 \mathrm{~min}$ in the absence or presence of the NMDA receptor antagonist MK801 $(100 \mu \mathrm{M})$. MK801 was added at $0 \mathrm{~min}$, NMDA $(100 \mu \mathrm{M})$ or quinpirole $(1 \mu \mathrm{M})$ at $10 \mathrm{~min}$, and SKF82526 $(1 \mu \mathrm{M})$ at $15 \mathrm{~min}$ of incubation. The amount of phospho-DARPP-32 was quantitated by densitometry, and the data were normalized to values obtained with SKF82526 alone. Data represent means \pm SEM for four to seven experiments. ${ }^{*} p<0.01$ compared with SKF82526/MK801 (-); ** $p<0.05$ compared with control/MK801 (-); *** $p<$ 0.01 compared with SKF82526/MK801 (+).

quinpirole to decrease the level of phospho-DARPP-32 occurs independently of the NMDA receptor. Treatment with M K801 increased the level of phospho-DARPP-32 under basal conditions, suggesting that in our preparation the NMDA receptor is tonically active and dephosphorylates DARPP-32 through activation of calcineurin.

\section{Effect of D2 agonist on the level of phospho-DARPP- 32 is not reduced by tetrodotoxin (TTX)}

It seemed possible that the D2-mediated decrease in DARPP-32 phosphorylation might involve release of a neurotransmitter from neurons other than those containing D1 receptors. Therefore, we tested the effect of TTX, an inhibitor of sodium-dependent action potentials, on the ability of quinpirole to affect DARPP-32 phosphorylation. TTX failed to reduce the effect of quinpirole (Table 3). TTX increased the levels of phospho-DARPP-32 under basal 
Table 3. Effect of D2 agonist on the level of phospho-DARPP-32 is not reduced by tetrodotoxin (TTX)

\begin{tabular}{lll} 
& TTX $(-)$ & TTX $(+)$ \\
\hline Control & $0.686 \pm 0.109$ & $1.000^{*}$ \\
SKF82526 & $3.282 \pm 0.575^{* *}$ & $5.492 \pm 0.780^{* * *, * * * *}$ \\
SKF82526 + quinpirole & $1.716 \pm 0.409^{*, * * *}$ & $1.968 \pm 0.559^{* * * * * *}$
\end{tabular}

Neostriatal slices were incubated for a total of $20 \mathrm{~min}$ in the absence or presence of TTX $(1 \mu \mathrm{M})$. TTX was added at 0 min, quinpirole $(1 \mu \mathrm{M})$ at $10 \mathrm{~min}$, and SKF82526 $(1 \mu \mathrm{M})$ at $15 \mathrm{~min}$ of incubation. The amount of phospho-DARPP-32 was quantitated by densitometry, and the data were normalized to values obtained with TTX alone. Data represent means \pm SEM for six to seven experiments. $* * p<0.01,{ }^{*} p<0.05$ compared with control/TTX (-); *** $p<0.05$ compared with SKF82526/TTX (-); $* * * * p<0.01$ compared with control/TTX $(+) ; * * * * * p<0.01$ compared with SKF82526/TTX $(+)$.

conditions or in the presence of SKF82526. The effect of TTX, like that of MK-801, supports the possibility that in our preparation the NMDA receptor is tonically active and dephosphorylates DARPP-32 through activation of calcineurin. The data provide no support for the possibility that quinpirole achieved its effect by release of a neurotransmitter from interneurons.

\section{DISCUSSION}

The results of this study demonstrate that DARPP-32 phosphorylation is regulated in mouse neostriatum through the opposing actions of D1- and D2-like dopamine receptors. Previous reports from this laboratory (Walaas et al., 1983; Walaas and Greengard, 1984) have shown that dopamine stimulates D1-like dopamine receptors in rat striatum, leading to sequential activation of adenylyl cyclase and cAMP-dependent protein kinase, and phosphorylation of DARPP-32 on $\mathrm{thr}^{34}$. The present results support the notion that dopamine-stimulated DARPP-32 phosphorylation is a D1 receptor-mediated effect and demonstrate that activation of D2-like dopamine receptors strongly reduces both the basal level of DARPP-32 phosphorylation and the phosphorylation of DARPP-32 stimulated by SKF82526, forskolin, and 8-bromocAMP. Thus, D1- and D2-like receptors have opposing effects on the activity of DARPP-32.

Adenylyl cyclase activity in the neostriatum is regulated through the opposing interactions of D1 and D2 receptors (Stoof and Kebabian, 1981). The inhibition of adenylyl cyclase activity by $\mathrm{D} 2$ receptors almost certainly contributes to the ability of quinpirole to reduce the phosphorylation of DARPP-32. However, such a mechanism does not fully explain the results of this study, because the activation of D2 receptors effectively decreases DARPP-32 phosphorylation induced by an exogenous cAMP analog, 8-bromo-cAMP. These data clearly indicate that a cAMP-independent pathway also participates in D2-receptor mediated regulation of DARPP-32.

One such mechanism by which quinpirole may reduce the phosphorylation of DARPP-32 is through an increase in the activity of a protein phosphatase(s) that dephosphorylates $\mathrm{thr}^{34}$ on DARPP-32. The calcium/calmodulin-dependent protein phosphatase calcineurin has been shown to dephosphorylate DARPP-32 with a high efficiency in vitro (King et al., 1984). The present study demonstrates that the ability of a D2 receptor agonist to reduce D1-stimulated DARPP-32 phosphorylation is blocked by the calcineurin inhibitor cyclosporin A. The data indicate that the activation of $\mathrm{D} 2$ receptors induces an increase in intracellular calcium and an activation of calcineurin in neostriatal neurons, leading to dephosphorylation of DARPP-32. It seems likely then that D2 agonists cause the dephosphorylation of

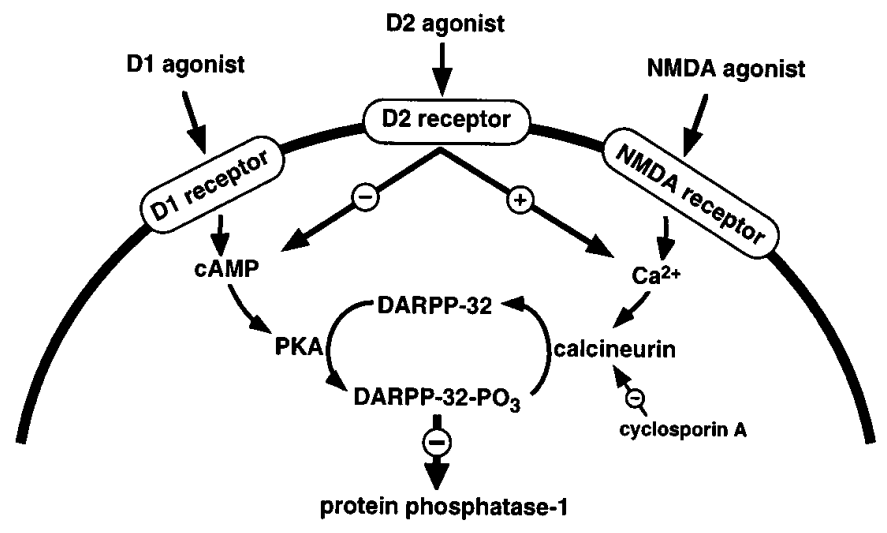

Figure 8. Postulated pathways by which dopamine may regulate DARPP-32 phosphorylation. Activation of D1 receptors increases cAMP, leading to the activation of PKA and the phosphorylation of DARPP-32 on thr $^{34}$, converting it into a potent inhibitor of protein phosphatase- 1 . Activation of D2 receptors decreases DARPP-32 phosphorylation by two mechanisms (which might occur in the same or in different groups of neurons): one involves an inhibition of adenylyl cyclase, a decrease in cAMP, a decrease in activity of PKA and a decreased phosphorylation of DARPP-32; the other involves an increase in intracellular $\mathrm{Ca}^{2+}$, an activation of calcineurin, and an increased dephosphorylation of $\mathrm{thr}^{34}$ phospho-DARPP-32. This scheme is supported by evidence showing that NMDA receptor activation (Halpain et al., 1990) and thapsigargin (present study), both of which raise intracellular $\mathrm{Ca}^{2+}$, cause the dephosphorylation of thr ${ }^{34}$-phospho-DARPP-32.

DARPP-32 both by reducing PKA-stimulated phosphorylation [e.g., Table 1B, cyclosporin A (+)] and by increasing calcineurinstimulated dephosphorylation (e.g., Fig. 5C). These dual effects of D2 receptor activation on DARPP-32 phosphorylation are shown in Figure 8.

Calcium omission induced a dramatic increase in the level of phospho-DARPP-32 in neostriatal slices and blocked D2mediated inhibition of DARPP-32 phosphorylation, further supporting a role for the calcium-dependent phosphatase in DARPP-32 regulation. Calcium omission increased DARPP-32 phosphorylation much more than did cyclosporin A treatment. This difference in effectiveness might be attributable to incomplete inhibition of calcineurin by cyclosporin A. Alternatively, other calcium-dependent processes could also contribute to the regulation of DARPP-32 phosphorylation. For instance, a major subtype of adenylyl cyclase, type V calcium-inhibitable adenylyl cyclase, is enriched in neostriatum (Cooper et al., 1995), and calcium omission would be expected to increase the activity of this enzyme, resulting in a potentiation of D1-stimulated DARPP-32 phosphorylation. In addition, the degradation of cAMP in neostriatum is mediated by a calcium-dependent phosphodiesterase activity (Polli and Kincaid, 1994), which would be anticipated to decrease under conditions of low calcium availability, leading to an additional mechanism for the potentiation of D1-stimulated DARPP-32 phosphorylation. Thus, physiological conditions that reduce intracellular calcium would be expected to decrease the driving force for calcium-dependent dephosphorylation and may also affect multiple signaling enzymes within neostriatal neurons to promote cAMP-dependent phosphorylation of DARPP-32 by PKA.

Recent studies have shown that multiple effectors, including potassium channels, calcium channels, and phospholipase $\mathrm{C}$, can be regulated by G-protein-mediated interactions with D2 receptors (Huff, 1996). The functional interaction of the D2 receptor 
with these effectors varies with the host cells and tissues that have been studied. For example, Yan and colleagues (1996) reported that D2 receptors on neostriatal neurons inhibit calcium channel conductances through interaction with a $\mathrm{G}_{\mathrm{i} / \mathrm{o}}$ class protein. Vallar et al. (1990) reported that D2 receptors expressed in pituitary GH4C1 cells decrease intracellular $\mathrm{Ca}^{2+}$ by inhibiting calcium channel activity, and that in contrast D2 receptors expressed in $\mathrm{Ltk}^{-}$fibroblasts increase intracellular $\mathrm{Ca}^{2+}$ by activating phospholipase C. A similar heterogeneity in $\mathrm{D} 2$ receptor effects on ion channel activity has been shown in neostriatal neurons by Surmeier et al. (1992), who demonstrated that D2 receptors could decrease sodium current in medium spiny neurons through a membrane-delimited pathway and increase it through a soluble second messenger pathway. Our results indicate that the effect of D2 receptors on DARPP-32 phosphorylation is calciumdependent and mediated by an increase in intracellular $\mathrm{Ca}^{2+}$ and an activation of calcineurin. It is possible that D2 receptors located on DARPP-32-containing neostriatal neurons mediate an increase in intracellular $\mathrm{Ca}^{2+}$ through regulation of potassium channels, calcium channels, or phospholipase C. The contributions of these various signal transduction pathways to the regulation of intracellular $\mathrm{Ca}^{2+}$, calcineurin activity, and DARPP-32 phosphorylation remain to be clarified. In addition, our data do not exclude the possibility that other D2-like receptors, including the D3 and D4 receptors, which are expressed in medium spiny neurons, albeit at low density (Surmeier et al., 1996), also contribute to signaling pathways responsible for calcineurindependent dephosphorylation of DARPP-32.

In principle, the effect of D2 agonists in causing the dephosphorylation of DARPP-32 might be attributable either to a direct effect on D1 receptor-containing neurons or to an indirect effect involving release of neurotransmitter from other neurons. In support of a direct action, Surmeier et al. (1996) reported that as many as $60 \%$ of the neostriatal neurons that contain D1-class receptors also contain D2-class receptors. Our data, indicating that quinpirole induces a $40 \%$ decrease in SKF82526-induced phosphorylation of DARPP-32, is consistent with a limited expression of D2- class receptors in D1 receptor-containing neurons. Activation of NMDA receptors that are ubiquitous on medium spiny neurons (Ghasemzadeh et al., 1996) induces a $100 \%$ decrease in SKF-induced phosphorylation of DARPP-32 (Table 2). Thus, the difference in the distribution of D2 and NMDA receptors may explain the greater efficacy of NMDA in reducing D1-stimulation of DARPP-32 phosphorylation.

Some groups have reported a very low degree of overlap of the two receptor classes (Gerfen et al., 1990; Hersch et al., 1995). Specifically, they report an apparent complete segregation of D1 and D2 receptors on dendrites (Hersch et al., 1995), with the possibility of up to a $20 \%$ colocalization of D1 and D2 receptors on neostriatal somata (Hersch et al., 1995). The results of these latter investigators would argue for an indirect mechanism for the action of quinpirole, involving the release, from non-D1 receptorcontaining neurons, of a neurotransmitter which, in turn, induces calcium-dependent activation of calcineurin and mediates DARPP-32 dephosphorylation in medium-sized spiny neurons. A similar mechanism has been proposed for the dephosphorylation of phospho-thr ${ }^{34}$-DARPP-32 in neostriatal neurons by the neuropeptide cholecystokinin (CCK) (Snyder et al., 1993). CCKmediated decreases in DARPP-32 phosphorylation are blocked by the NMDA receptor antagonist MK801, which suggests that CCK regulates DARPP-32 by release of excitatory amino acids like glutamate and aspartate from either corticostriatal nerve terminals or interneurons. The D2-mediated release of a neurotransmitter from interneurons seems unlikely to be involved in the D2-mediated decrease in DARPP-32 phosphorylation, because TTX, an inhibitor of sodium-dependent action potentials, did not block the D2 agonist effect (Table 3). In addition, the present study indicates that although the activation of NMDA receptors, like that of D2 receptors, decreases basal and D1-stimulated DARPP-32 phosphorylation in neostriatal slices through stimulation of calcineurin, these effects are independent, because the D2 receptor effect was not blocked by MK801, an NMDA receptor antagonist.

It is widely believed that a relative hyperactivity within mesolimbic and/or nigrostriatal dopaminergic systems contributes to the etiology of schizophrenia (Davis et al., 1991). This hypothesis is based largely on studies of the mechanism of action of neuroleptic medications. The therapeutic efficacy of antipsychotic drugs is linked to their ability to block dopamine receptors, particularly those that interact with D2-like dopamine receptors (for review, see Seeman, 1992). Typical antipsychotic drugs have been reported to antagonize the inhibitory effect of D2 receptors on adenylyl cyclase (Onali et al., 1985), to increase Fos expression (Dragunow et al., 1990), and to affect the expression of glutamate receptor subunits (Fitzgerald et al., 1995). In the present study, we have demonstrated that raclopride, a widely used antipsychotic, increases the phosphorylation of DARPP-32 in basal and D2 receptor-activated conditions in slices of neostriatum and nucleus accumbens, implicating a DARPP-32/protein phosphatase-1 pathway in the actions of this and other antipsychotic drugs. Raclopride also blocked D2-mediated inhibition of D1-stimulated DARPP-32 phosphorylation in neostriatum and nucleus accumbens. The nucleus accumbens is a target for mesolimbic dopaminergic projections (Swanson, 1982) that has been implicated in the genesis of psychotic symptoms (Davis et al., 1991).

The notion that the action of antipsychotic drugs might be mediated through increasing DARPP-32 phosphorylation is made more interesting by a recent report showing that treatment with a D1 antagonist (SCH39166) does not improve but actually worsens the symptoms of schizophrenia (Karlsson et al., 1995). D1 antagonists, like D2 agonists, would be expected to inhibit increases in DARPP-32 phosphorylation. The increased DARPP-32 phosphorylation, observed in response to raclopride treatment, would be expected to inhibit protein phosphatase-1 activity, resulting in an increase in the state of phosphorylation of various substrates that contribute to the regulation of neuronal excitability. There is evidence that the D1/DARPP-32/protein phosphatase-1 cascade regulates the state of phosphorylation and/or the activity of the electrogenic sodium pump $\mathrm{Na}^{+}, \mathrm{K}^{+}$ATPase (Nishi et al., 1996), calcium channels (Surmeier et al., 1994), voltage-dependent sodium channels (Surmeier et al., 1992; Schiffman et al., 1994), and the glutamate receptor subunit NR1 (Snyder et al., 1996). The mechanism by which alterations in the state of phosphorylation of these and other substrates of protein phosphatase- 1 contribute to the action of antipsychotic drugs represents an interesting challenge for future investigations.

\section{REFERENCES}

Aitkin A, Bilham T, Cohen P (1982) Complete primary structure of protein phosphatase inhibitor-1 from rabbit skeletal muscle. Eur J Biochem 126:235-246.

Anden NE, Carlsson A, Dahlstrom A, Fuxe K, Hillarp NA, Larsson K (1964) Demonstrating and mapping out of nigroneostriatal dopamine neurons. Life Sci 3:523-530.

Aperia A, Fryckstedt J, Svensson L-B, Hemmings Jr HC, Nairn AC, 
Greengard P (1991) Phosphorylated $M_{\mathrm{r}} 32,000$ dopamine- and cAMPregulated phosphoprotein inhibits $\mathrm{Na}^{+}, \mathrm{K}^{+}$-ATPase activity in renal tubule cells. Proc Natl Acad Sci USA 88:2798-2801.

Cooper DM, Mons N, Karpen JW (1995) Adenylyl cyclases and the interaction between calcium and cAMP signaling. Nature 374:421-424

Davis KL, Kahn RS, Ko G, Davidson M (1991) Dopamine in schizophrenia: a review and reconceptualization. Am J Psychiat 148:1474-1486.

Dragunow M, Robertson GS, Faull RL, Robertson HA, Jansen K (1990) D2 dopamine receptor antagonists induce fos and related proteins in rat striatal neurons. Neuroscience 37:287-294.

Fitzgerald LW, Deutch AY, Gasic G, Heinemann SF, Nestler EJ (1995) Regulation of cortical and subcortical glutamate receptor subunit expression by antipsychotic drugs. J Neurosci 15:2453-2461.

Gerfen CR, Engber TM, Mahan LC, Susel Z, Chase TM, Monsma Jr FJ, Sibley DR (1990) D1 and D2 dopamine receptor-regulated gene expression of striatonigral and striatopallidal neurons. Science 250:1429-1432.

Ghasemzadeh MB, Sharma S, Surmeier DJ, Eberwine JH, Chesselet M-F (1996) Multiplicity of glutamate receptor subunits in single striatal neurons: an RNA amplification study. Mol Pharmacol 49:852-859.

Halpain S, Girault J-A, Greengard P (1990) Activation of NMDA receptors induced dephosphorylation of DARPP-32 in rat striatal slices. Nature 343:369-372.

Hemmings Jr HC, Greengard P (1986) DARPP-32, a dopamine- and adenosine $3^{\prime}: 5^{\prime}$-monophosphate-regulated phosphoprotein: regional, tissue, and phylogenetic distribution. J Neurosci 6:1469-1481.

Hemmings Jr HC, Greengard P, Tung HYL, Cohen P (1984) DARPP32 , a dopamine-regulated neuronal phosphoprotein, is a potent inhibitor of protein phosphatase-1. Nature 310:503-505.

Hersch SM, Ciliax BJ, Gutekunst CA, Rees HD, Heilman CJ, Yung KK, Bolam JP, Ince E, Yi H, Levey AI (1995) Electron microscopic analysis of D1 and D2 dopamine receptor proteins in the dorsal striatum and their synaptic relationships with motor corticostriatal afferents. J Neurosci 15:5222-5237.

Huff RM (1996) Signal transduction pathways modulated by the $D_{2}$ subfamily of dopamine receptors. Cell Signal 8:453-459.

Jackson DM, Westlind-Danielsson A (1994) Dopamine receptors: molecular biology, biochemistry and behavioral aspects. Pharmacol Ther 64:291-370.

Karlsson P, Smith L, Farde L, Harnryd C, Sedvall G, Wiesel FA (1995) Lack of apparent antipsychotic effect of the D1-dopamine receptor antagonist SCH39166 in acutely ill schizophrenic patients. Psychopharmacology 121:309-316.

King MM, Huang CY, Chock PB, Nairn AC, Hemmings Jr HC, Chan K-FJ, Greengard P (1984) Mammalian brain phosphoproteins as substrates for calcineurin. J Biol Chem 259:8080-8083.

Levey AI, Hersch SM, Rye DB, Sunahara RK, Niznik NB, Kitt CA, Price DL, Maggio R, Brann MR, Ciliax BJ (1993) Localization of D1 and D2 dopamine receptors in brain with subtype-specific antibodies. Proc Natl Acad Sci USA 90:8861-8865.

Nishi A, Snyder GL, Fienberg A, Allen P, Fisone G, Nairn AC, Aperia A, Greengard P (1996) Role of DARPP-32 in the regulation of $\mathrm{Na}^{+}, \mathrm{K}^{+}$ATPase activity in striatal neurons. Soc Neurosci Abstr 22:380.

Onali P, Olianas MC, Gessa GL (1985) Characterization of dopamine receptors mediating inhibition of adenylate cyclase activity in rat striatum. Mol Pharmacol 28:138-145.

Ouimet CC, Miller PE, Hemmings Jr HC, Walaas SI, Greengard P (1984) DARPP-32, a dopamine- and adenosine $3^{\prime}: 5^{\prime}$-monophosphateregulated phosphoprotein enriched in dopamine-innervated brain regions. III. Immunocytochemical localization. J Neurosci 4:114-124.

Poirier LJ, Sourkes TL (1965) Influence of the substantia nigra on the catecholamine content of the striatum. Brain 88:181-192.
Polli JW, Kincaid RL (1994) Expression of calmodulin-dependent phosphodiesterase isoform (PDE1B1) correlates with brain regions having extensive dopaminergic innervation. J Neurosci 14:1251-1261.

Schiffman SN, Lledo P-M, Vincent J-D (1994) Dopamine D1 receptor modulates the voltage-gated sodium current in rat striatal neurons through a protein kinase. Am J Physiol 483:95-107.

Seeman P (1992) Dopamine receptor sequences. Therapeutic levels of neuroleptics occupy D2 receptors: clozapine occupies D4. Neuropsychopharmacology 7:261-284.

Seeman P, Van Tol HH (1994) Dopamine receptor pharmacology. Trends Pharmacol Sci 15:264-270.

Sibley DR, Monsma Jr FJ (1992) Molecular biology of dopamine receptors. Trends Pharmacol Sci 13:61-69.

Snyder GL, Girault J-A, Chen JYC, Czernik AJ, Kebabian JW, Nathanson JA, Greengard P (1992) Phosphorylation of DARPP-32 and protein phosphatase inhibitor-1 in rat choroid plexus: regulation by factors other than dopamine. J Neurosci 12:3071-3083.

Snyder GL, Fisone G, Morino P, Gundersen V, Ottersen OP, Hökfelt T, Greengard P (1993) Regulation by the neuropeptide cholecystokinin (CCK-8S) of protein phosphorylation in the neostriatum. Proc Natl Acad Sci USA 90:11277-11281.

Snyder GL, Fienberg A, Dulubova I, Nairn AC, Greengard P (1996) Dopamine-mediated phosphorylation of NMDA-R1 in the rat nucleus accumbens. Soc Neurosci Abstr 22:380.

Stoof JC, Kebabian JW (1981) Opposing roles for D-1 and D-2 dopamine receptors in efflux of cyclic AMP from rat neostriatum. Nature 294:366-368.

Surmeier DJ, Eberwine J, Wilson CJ, Cao Y, Stefani A, Kitai ST (1992) Dopamine receptor subtypes colocalize in rat striatonigral neurons. Proc Natl Acad Sci USA 89:10178-10182.

Surmeier DJ, Bargas J, Hemmings Jr HC, Nairn AC, Greengard P (1994) Differential modulation of calcium currents by the D1 dopaminergic signaling pathway in rat neostriatal neurons. Neuron 14:385-397.

Surmeier DJ, Song WJ, Yan Z (1996) Coordinated expression of dopamine receptors in neostriatal medium spiny neurons. J Neurosci 16:6579-6591.

Swanson LW (1982) The projections of the ventral tegmental area and adjacent regions: a combined fluorescent retrograde tracer and immunofluorescence study in the rat. Brain Res Bull 9:321-353.

Thastrup O, Cullen PJ, Drobak BK, Hanley MR, Dawson AP (1990) Thapsigargin, a tumor promoter, discharges intracellular $\mathrm{Ca}^{2+}$ stores by specific inhibition of the endoplasmic reticulum $\mathrm{Ca}^{2+}$-ATPase. Proc Natl Acad Sci USA 87:2466-2470.

Towbin H, Staehlin T, Gordon J (1979) Electrophoretic transfer of proteins from polyacrylamide gels to nitrocellulose sheets: procedure and some applications. Proc Natl Acad Sci USA 76:4350-4354.

Vallar L, Muca C, Magni M, Albert P, Bunzow J, Meldolesi J, Civelli O (1990) Differential coupling of dopaminergic D2 receptors expressed in different cell types. J Biol Chem 265:10320-10326.

Walaas SI, Greengard P (1984) DARPP-32, a dopamine- and adenosine $3^{\prime}: 5^{\prime}$-monophosphate-regulated phosphoprotein enriched in dopamineinnervated brain regions. I. Regional and cellular distribution in rat brain. J Neurosci 4:84-98.

Walaas SI, Aswad DW, Greengard P (1983) A dopamine- and cyclic AMP-regulated phosphoprotein enriched in dopamine-innervated brain regions. Nature 301:69-71.

Williams KR, Hemmings Jr HC, LoPresti MB, Konigsberg WH, Greengard P (1986) DARPP-32, a dopamine- and cyclic AMP-regulated neuronal phosphoprotein. Primary structure and homology with protein phosphatase inhibitor-1. J Biol Chem 261:1890-1903.

Yan Z, Song W-J, Surmeier DJ (1996) Activation of $\mathrm{D}_{2}$ dopamine receptors reduces $\mathrm{Ca}^{2+}$ currents in rat neostriatal cholinergic interneurons. Soc Neurosci Abstr 22:1088. 